\title{
AGROECOLOGICAL PRACTICES AS SUSTAINABLE MANAGEMENT OF COMMON NATURAL RESOURCES: THE CASE OF LATVIAN PERMACULTURE MOVEMENT
}

\author{
*Elgars Felcis \\ University of Latvia, Latvia \\ *Corresponding author's email: elgars.felcis@lu.lv
}

\begin{abstract}
Scientific evidence is robust about the environmentally destructive side-effects of the current industrial civilization and that requires radical actions to safeguard sustainable management of natural resources and liveable Planet Earth. Agroecology as a broader movement serves some of this role in demonstrating alternative practices in food production and ecosystem management. This paper demonstrates that the permaculture movement in Latvia is developing as a recognized alternative on the pathway to solutions, linking to the work elsewhere done on management of common natural resources - the things that no one owns and are shared by everyone. The author have explored the development of the permaculture movement in Latvia since its first roots in the late 2000s and the establishment of the Latvian Permaculture Association (LPA) in 2011. The contribution of the movement manifests itself in diverse aspects. It unifies various sustainability-oriented people, grounds itself in locality and traditions, organises practically oriented events to upskill people, and collaborates with Latvian environmental organisations and internationally. Within the research the author consciously opted for an in-depth involvement and co-creation of initiatives within the permaculture movement, leading the LPA since 2016 and organizing multiple events and workshops. That leads to further reflections on the role and necessity for participatory action research for sustainability transformations and common natural resources.
\end{abstract}

Key words: agroecology, permaculture, commons, regeneration, sustainability transformations, participatory action research.

\section{Introduction}

'The philosophy behind permaculture is one of working with, rather than against, nature' (Mollison, 1988). World scientists are issuing 'warnings to humanity' (Ripple et al., 2017) that we are indeed working 'against nature' - many concerns relate to the current land management practices that are affected by the climate crisis (IPCC, 2018; IPCC, 2019), contributing to the ongoing biological annihilation (Ceballos et al., 2017) and one million species at risk of extinction (IPBES, 2019) as sideeffects of our development and growth (Beck, 2009). One of the worldwide responses to such dilemmas is agroecology and within it the permaculture movement (Mollison \& Holmgren, 1978) which is, however, little covered in the scientific literature (Ferguson \& Lovell, 2014).

It is reasonable to argue that 'permaculture' has been practiced for thousands of years and still is somewhere practiced by people who have never heard of permaculture. The term itself was formulated in the 1970s by two Australians, Bill Mollison and David Holmgren (1978). Initially, it was predominantly focused on the agricultural aspects as in 'permanent agriculture' and attempts to mimic natural ecosystems, for example, in forest gardens, but it has developed over time and continues to change and develop. By the early 1990s permaculture already has been redefined as '.... a design system for creating sustainable human environments. The word itself is a contraction not only of permanent agriculture but also of permanent culture, as cultures cannot survive long without a sustainable agricultural base and land use ethic.' (Mollison \& Slay, 1991).

Permaculture as both philosophical and practical framework is establishing itself as reliable in transformative action (Henfrey, 2018). Permaculture is probably the best-known movement within a broader global agroecological movement but has been relatively neglected in the scientific literature in spite of the high level of general interest and widespread practice in already most of the world (Ferguson \& Lovell, 2014; Hathaway, 2016; Rhodes, 2012). For example, it is one of the key inspirations in the development of the international Transition Network that now covers more than 50 countries and thousands of transition groups (Hopkins, 2011). Such examples highlight the role the permaculture movement can play beyond the focus on alternative agroecological practices and provide a broader ethical and philosophical guidance to transcend current unsustainable paradigms (Gopel, 2016) and develop regenerative 'permanent cultures'. In essence, permaculture is not only about particular practices, but about changes in the whole lifestyles to be regenerative - to turn the human negative ecological impact into a positive one.

A common line of criticism is summed up by Ferguson and Lovell (2014) who claim that permaculture literature tends to have 'simple solution populism'. In other words, solutions to environmental and social crises are both simple and known and hence permaculture only requires the recombination of the existing knowledge rather than the generation of new knowledge (Mollison \& Holmgren, 1978). 
On the contrary, in permaculture literature academic institutions and researchers are commonly criticized for conservativism, slow pace of change, lack of vision, and strong ties to unsustainable corporate interests (Mollison \& Holmgren, 1978; Mollison, 1988; Shepard, 2013). One of the origins for this stance is the university colleagues' rejection of Mollison's plea for a cross-disciplinary holistic approach in the 1970s. His work was one of the first attempts to develop a regenerative design approach that drew on the knowledge of traditional cultures while adapting to the opportunities of new technologies and systems thinking.

The core ethics of permaculture can be summarised in the threefold: 'Earth care, people care and fair share' (Holmgren, 2002). That resonates with ongoing discussion in environmental philosophy and ethics about the risks associated with anthropocentrism and related risks of ecosystem and resource exploitation (Keller, 2010; Kingsnorth, 2017). It is essential to see permaculture not as a revolutionary novel approach to farming or living, but as an overall framework that brings together many diverse environmental ideas in a coherent pattern. Most of the specific ideas and practices under the heading of permaculture are not unique to it and were not originated by people who call themselves 'permaculturists' (Whitefield, 2004). Ironically, in that sense permaculture does reflect the ideal of scientific knowledge accumulation in Newtonian 'standing on the shoulders of giants', however, permaculture covers a broad spectrum of disciplines and focuses on human and ecosystem longterm well-being and permanent solutions through practical action. Therefore, it is useful as a holistic framework to advance sustainability transformations and management of common natural resources in Latvia and this article demonstrates the current achievements and challenges.

As mentioned above, permaculture is relatively neglected in the scientific literature internationally and in Latvia and hence this paper aims to summarise the history and development of the permaculture movement in Latvia, its support for transformative regenerative actions, and contributions to the management of common natural resources through participatory action research approach.

\section{Materials and Methods}

This paper is based on an ongoing participatory action research with a wide spectrum of involvement avenues in sustainability-oriented initiatives in Latvia beginning in 2016. The research was initiated within a broader research network - Marie Curie Innovative Training Network SUSPLACE (www.susplace.net) and is further advanced during the Latvian Council of Science funded project 'Ready for change?
Sustainable management of common natural resources (RfC)'. The logic of such participatory action research includes, firstly, synthesis of natural and climate science evidence of the immense sustainability transformations required and, secondly, engagement in active knowledge brokerage and societal change advancement, including management of commons.

Essentials for action-oriented, transformations and climate change research, summarized on the basis of individual and collective outputs in two-year collaboration of almost 50 scientists (Fazey et al., 2018) are reflected in much of the author's work carried out since 2016 in Latvia. The essentials recommended are based on the expressed need for 'massive upscaling of research that can rapidly enhance learning about transformations:

1) Focus on transformations to low-carbon, resilient living; 2) Focus on solution processes; 3) Focus on 'how to' practical knowledge; 4) Approach research as occurring from within the system being intervened; 5) Work with normative aspects; 6) Seek to transcend current thinking; 7) Take a multi-faceted approach to understand and shape change; 8) Acknowledge the value of alternative roles of researchers; 9) Encourage second-order experimentation; 10) Be reflexive' (Fazey et al., 2018). Such essentials indicate that research itself needs to undergo fundamental changes if it wants to contribute to sustainability transformations and regeneration.

The summary of Julia Wittmayer methodological contribution in her research on 'Transition Management, Action Research and Actor Roles: Understanding local sustainability transitions' (2016) outlines the types of advantages and challenges the author is also experiencing in the research - actionoriented approaches are 'creating spaces for reflexivity, interaction and learning and in generating scientific, social and reflexive knowledge as well as actual action and thus supporting sustainability transitions whilst studying them. These approaches are challenging in the actual operationalization in messy, contested and diverse contexts, which put high demands on researcher's identity and integrity' (Wittmayer, 2016: 260).

A particular difficulty of research addressing societal problems arising from sustainability problems is the explicit normative component that inevitably arises. A researcher spending years studying sustainability challenges or regeneration potential is likely to struggle to provide an open-ended process in discussing sustainability definition and approaches, but instead will be inclined towards a more normative standpoint stemming from the informed position as to what actions should be preferential to lead to more sustainability. Such paradoxes 'cannot be solved in general terms but only through being embedded in a specific local context, which is where questions of 
ethics and normativity arise' (Wittmayer, 2016: 255).

Therefore, this paper provides insights in attempts to do so in the particular circumstances of Latvia researching the ongoing processes and leading or cocreating multiple activities since 2016 :

a) two internationally recognised Permaculture Design Certificate (PDC) courses in 2017; b) The Diploma in Applied Permaculture process initiated in 2018 and the first Diploma holder graduation in 2020; c) Plans for the PDC course in Latvian tailored to the local needs in 2021; d) five annual permaculture festivals with multiple lectures and practical workshops; e) more than ten Rocket Mass Heater (RMH) practical workshops; f) six successful project applications and implementation (completed and ongoing - Nordplus, Erasmus+, LEADER LAGs, Latvian Environmental Protection Fund, Society Integration Foundation); g) $>10$ national-level radio appearances on permaculture, climate change and degrowth; h) more than ten university guest lectures in four different Latvian universities to students of economics, management, sociology, agriculture and eco-technologies - about sustainability science, permaculture, degrowth and participatory action research; i) more than ten public lectures in various settings, for example, the annual discussion festival LAMPA; j) Leading the Latvian Permaculture Association (LPA) as its chairman since 2016; k) Leading the multifunctional open permaculture homestead 'Zadini' and the foundation 'Zadini' since 2018.

Co-created events and activities are providing diverse sources of information and data. Firstly, photos and video material of events and daily work. Secondly, in-depth insights into the day-to-day operation of permaculture activists and homesteads (including recorded interview and discussion material). Thirdly, evaluation material from workshop participants (quantitative and qualitative). Fourthly, overall development of in-depth insight about the people interested in permaculture practices and their individual steps towards sustainability and regeneration - from multiple workshops, seminars and the permaculture festivals.

However, the aim in the participatory action research process is not only to document some of the sustainability-oriented actions based on people's claims in interviews, evaluations or discussions, but predominantly to contribute to sustainability transformations and management of common natural resources in the society through co-creation of activities, events, workshops and longer lasting collaborative networks as summarised above.

\section{Results and Discussion}

The LPA was chosen in the author's research and activism as one of key entry points to contribute to sustainability transformation and management of common natural resources in Latvia. The LPA is founded in late 2011. However, the first encounters with permaculture as a theoretical and practical framework happened when Latvian organic farmers visited Austria in late 2000s. In the foundation of the LPA some farmers were joined by various enthusiasts across the country who had encountered permaculture as a part of solution to the various sustainability problems of the world that they had been trying to understand. The LPA includes a wide variety of Latvian population, foreigners in Latvia and Latvians living abroad.

The author has been elected chairman of it since the spring 2016, and the number of its members doubled from 68 to 150 in early 2021. $23 \%$ of its members live in Riga, $23 \%$ in a near proximity to it - Pierīga, 27\% live in the Vidzeme region and less in other regions $-11 \%$ in Kurzeme, $7 \%$ in Latgale and Zemgale and 4\% abroad.

The new LPA website (www.permakultura.lv) was launched in April 2017 and its visitors have more than doubled if to compare the April-December 2017 with the April-December 2018 and increased further in 2019 and 2020. There are remarkable daily visitor peaks before bigger events and after public appearances on the radio or other media about permaculture. The Facebook Latvian permaculture group (www.facebook.com/permakultura.lv) has also multiplied its follower numbers since 2016, exceeding 2500 in early 2021.

These quantifications correspond to qualitative research evidence that the LPA has become recognised as a practically oriented environmental Non-Governmental Organisation (NGO) among other Latvian environmental organisations and multiple people from the organisation are regularly invited to relevant discussions, film screenings, petition signings and protests. This is the privilege of a relatively small country like Latvia that it is possible to quickly personally get to know a whole range of people if the activities are relevant, ambitious and compelling.

Further recognition of the permaculture practices as alternatives in agricultural practices and management of commons is through the work of LPA members within the Latvian Rural Advisory and Training Centre (LLKC). In 2020 and 2021, there have already been multiple LLKC seminars including topics of permaculture and agroecology, and there are further expressions of interest from the regional LLKC branches. The attitude within the LLKC has been significantly shifting, especially within the last five years in recognition of need and feasibility of agricultural and resource management practices that are regenerative (organic farming, agroecology, permaculture) and help to reduce the risks of 
environmental breakdown and improve the capacity to somewhat adapt to that.

Many of the practices in permaculture are aiming for regeneration as indicated in the sub-title 'Principles and pathways beyond sustainability' and re-appearing throughout the 12 core permaculture principles:

1. Observe and interact; 2 . Catch and store energy; 3. Obtain a yield; 4. Apply self-regulation and accept feedback; 5. Use and value renewable resources and services; 6. Produce no waste; 7. Design from patterns to details; 8. Integrate rather than segregate; 9. Use small and slow solutions; 10 . Use and value diversity; 11. Use edges and value the marginal; 12. Creatively use and respond to change (Holmgren, 2002).

This is not a strict list of principles every 'permaculturist' should or does follow, but rather this is an important guide towards an overall ecologically aware and embodied lifestyle. Some people in the organic farming movement admit that it often lacks the coherent set of ecological ideas/worldviews, or, in other words, ideology. Permaculture is useful in providing this encouraging ideology and personal integrity for any actions that one takes.

The LPA is also a member or in regular contacts with multiple relevant international organisations - European Permaculture Network (EUPN), ECOLISE Network, Global Ecovillage Network, Baltic Ecovillage Network, Transition Network, Nordic Permaculture Institute, Danish Ecovillage Association, Finnish Permaculture Association, Estonian Permaculture Association (founded in April 2018), Small Footprint Ecovillage (Estonia), Suderbyn Permaculture Ecovillage (Sweden) and others.

Together with different LPA members there have been several successful project applications that are oriented towards achieving aims that are aligning with the permaculture principles, resilient, regenerative lifestyles, and sustainable management of common pool resources, for example:

1. 'School gardens for Latvian Centenary'-creation of co-designed permaculture school gardens by four Latvian schools and website creation with advice for other schools to follow the example (www.skoludarzi. net, Latvian Environmental Protection Fund, 2017 2018); 2. 'Growing Seed Savers: Baltic-Nordic Seed Savers Education Innovation' - development of seed saving database, international experience exchange and popularisation of seed sharing practices with partners in Estonia, Lithuania and Denmark (https:// growingseedsavers.org, Nordplus, 2018-2020); 3. 'OFF-GRID: Renewable Energy Do-It-Yourself for rural development' - targeting specifically selfsufficiency energetically and technically of those that are not already financially privileged and running practical workshops in three Latvian regions, creation of open source paper and online handbook for self-build installations and devices; in total 10 partners in 5 Baltic Sea Region countries - Sweden, Finland, Estonia, Latvia and Lithuania (LEADER LAGs, 2018-2020); 4. 'Support to the Latvian Permaculture Association for popularisation of sustainable agriculture in Latvia' (www.permakultura. lv/ilgtspejiga-lauksaimnieciba.html, www.mantots. permakultura.lv, Society Integration Foundation, 2020); 5. Media campaign 'Alive Earth' within the Society Integration Foundation (SIF) funded project with regular press releases, articles and social media posts throughout 2020 - regarding pesticide use, pesticide drift, sustainable agricultural practices etc. (http://www.permakultura.lv/dziva-zeme.html); 6. 'Eco-active for Planet' - project coordinated by the NGO Trainers' Association in Poland, with partners from Czechia, Finland, Luxembourg (Erasmus+, 2020-2022).

There are multiple pathways of project implementation with the involvement of the LPA. Sometimes projects are submitted directly by the LPA, in other projects the LPA is included as the partner and on other occasions the projects are submitted through other NGOs of active LPA members or in collaboration with the Local Action Groups (LEADER). The active LPA members are very resourceful and persistent in trying to secure support for the ideas that make sense for rural resilience development and permaculture. Projects are predominantly initiated on the basis of advancing quicker the sustainability transformations that permaculturists would like to see anyway and that would be slower or not possible without the grant funding.

The overarching theme that enables the multistakeholder involvement is the openness for others to learn what is done in the homesteads of the LPA members and how the owners can inspire and empower others in reception of voluntary workers, aspiring back-to-the-landers, permaculture enthusiasts and journalists. Indeed, since 2016 permaculture related activities and places increasingly more often appear on local and national radio, TV and YouTube channel episodes as well as on newspaper and journal articles. The campaign 'Alive Earth' during 2020 was a particularly recognizable in that respect and resonated well with growing Latvian societal sentiments about the dangers of pesticide use and pesticide drift. Throughout the year both LPA official membership and following on Facebook was rising faster than in 2019 or 2018 . The representatives from the State Plant Protection Service (www.vaad.gov.lv) that is in charge of permissions for plant protection substances and monitoring of their use in several personal discussions have admitted that the activity of people in reporting possible breaches in pesticide use has been unprecedented in 2020 . 
The continuous work through several LPA projects on the seed saving and heritage heirloom seeds is an important work in the direction of maintaining the plant genetic diversity as common pool resource. David Bollier also recognizes the work of the permaculture movement among other in resurrecting heirloom varieties (Bollier, 2014: 50). Annual seed exchanges in the beginning of the year is the longest-running LPA event for over a decade. In early 2020 this event was joined with the seed savers weekend-long training and in early 2021 this training was brought online with three whole-day sessions that brought more than 60 people in attendance.

The biggest annual event of the LPA is Permaculture Festival that was running for the $7^{\text {th }}$ time in the summer 2020 (www.permakultura.lv/ festivals.html). Since 2016 it is annually attended by $120-180$ people and $30-50$ of them are children, indicating about the friendly atmosphere for all generations and appeal that permaculture ideas are appreciated among families thinking of the future of their children. The festival traditionally includes a combination of lectures and practical workshops in a wide range of issues LPA members have expertise about - practitioners on the Diploma in Applied Permaculture pathway are forming the core group of teachers, supplemented by other active LPA members. The ongoing funded project outputs are always incorporated in the festival program, for example, the OFF-GRID project workshops were tailored with the 2019 and 2020 festival. Throughout the years there is a strong emphasis on practitioners and people speaking from their experience of applying various agroecological and permaculture theories into practice and Latvian climatic conditions. Practical workshops also include 'forest walks' or 'field walks' with lively discussions about the biological diversity of different ecosystems and what human management approaches can be to manage those common natural resources sustainably and regeneratively. The practices include sustainable forestry approaches without clear-cuts, forest gardens, silvo-pastures, holistic management of grazing systems and other approaches benefiting from various aspects of plant succession and mimicking ecosystem functioning.

\section{Conclusions}

In conclusion, this paper has explored the role of the permaculture movement in supporting regeneration, and it can be concluded that permaculture in Latvia is contributing to sustainability and management of commons in several aspects. Firstly, the permaculture movement already reaches diverse types of people in Latvia, allowing them to relate to the movement - city dwellers, recent and aspiring 'back-to-the-landers', small town inhabitants, and rural people; each group finding different aspects of permaculture as useful for their further paths. Secondly, it roots itself in locality and traditions, building national-level recognition and trust through social activism and media appearances. Thirdly, there are multiple events that provide practical examples, know-how and empowers people to make further changes in their lives. Fourthly, the movement connects with other environmental organisations and strengthens the Latvian network acting on a broad range of environmental and climate issues. Fifthly, a national practitioner network and collaborative networks within the Baltic Sea region are continuously developing.

However, simultaneously several challenges arise. In spite of the successes and growing popularity, the permaculture movement in Latvia is largely driven by the above mentioned activists and a relatively narrow circle of skilled, experienced, motivated, and proactive people. The LPA has developed substantially as an organisation since 2016, but remains relatively vulnerable in its structural resilience. These are common issues in the NGO sector and grassroots activities in Latvia as a small country with a troubled history and still inexperienced civic society. The change and transformations can be driven fast, but simultaneously the successes can be fragile because of the dependency on relatively few leaders.

Furthermore, some criticism also relates to the scale of influence the permaculture movement has. It does contribute to lifestyle changes, sustainability transformations, regeneration and teaches about the management of common natural resources, but many people still struggle to alter their life status-quo in the face of dominant consumer-culture and permaculture risks to remain as the change factor for incremental change with the same unsustainable fundamentals. However, with the scale of the challenges, risks, and catastrophes ahead, the permaculture principles and practices are likely to maintain their appeal and assist in the much-needed sustainability transformations through reforms or further crises.

\section{Acknowledgements}

This research is funded by the Latvian Council of Science, project "Ready for change? Sustainable management of common natural resources (RfC)", project No. lzp-2019/1-0319.

\section{References}

Beck, U. (2009). World at Risk. Cambridge: Polity Press.

Bollier, D. (2014). Think Like a Commoner. A Short Introduction to the Life of the Commons. Gabriola Island: New Society Publishers. 
Ceballos, G., Ehrlich, P.R., \& Dirzo, R. (2017). Biological annihilation via the ongoing sixth mass extinction signaled by vertebrate population losses and declines. Proceedings of the National Academy of Sciences of the United States of America (PNAS), 114 (30), 6089-6096. DOI: 10.1073/pnas.1704949114.

Fazey, I., Schäpke, N., Caniglia, G., Patterson, J., Hultman, J., van Mierlo, B., ... Wyborn, C. (2018). Ten essentials for action-oriented and second order energy transitions, transformations and climate change research. Energy Research \& Social Science, 40, 54-70. DOI: 10.1016/j.erss.2017.11.026.

Ferguson, S.R., \& Lovell, S.T. (2014). Permaculture for agroecology: design, movement, practice, and worldview. A review. Agronomy for Sustainable Development, 34, 251-274. DOI: 10.1007/s13593-0130181-6.

Gopel, M. (2016). The Great Mindshift. How a New Economic Paradigm and Sustainability Transformations go Hand in Hand. Springer Open. Retrieved March 10, 2021, from https://link.springer.com/content/ pdf/10.1007\%2F978-3-319-43766-8.pdf.

Hathaway, M.D. (2016). Agroecology and permaculture: addressing key ecological problems by rethinking and redesigning agricultural systems. Journal of Environmental Studies and Sciences, 6, 239-250. DOI: $10.1007 / \mathrm{s} 13412-015-0254-8$.

Henfrey, T.W. (2018). Designing for resilience: permaculture as a transdisciplinary methodology in applied resilience research. Ecology and Society, 23(2), 33. DOI: 10.5751/ES-09916-230233.

Holmgren, D. (2002). Permaculture: Principles and Pathways beyond Sustainability. Victoria, Australia: Holmgren Design Services.

Hopkins, R. (2011). The Transition Companion: Making Your Community More Resilient in Uncertain Times. Cambridge: Green Books.

IPBES (2019). Summary for policymakers of the global assessment report on biodiversity and ecosystem services of the Intergovernmental Science-Policy Platform on Biodiversity and Ecosystem Services. IPBES secretariat, Bonn, Germany. Retrieved March 10, 2021, from https://www.ipbes.net/global-assessmentreport-biodiversity-ecosystem-services.

IPCC (2018). Global Warming of $1.5^{\circ} \mathrm{C}$. An IPCC Special Report on the impacts of global warming of $1.5^{\circ} \mathrm{C}$ above pre-industrial levels and related global greenhouse gas emission pathways, in the context of strengthening the global response to the threat of climate change, sustainable development, and efforts to eradicate poverty. Retrieved March 10, 2021, from www.ipcc.ch/report/sr15/.

IPCC (2019). Summary for Policymakers. In: Climate Change and Land: an IPCC special report on climate change, desertification, land degradation, sustainable land management, food security, and greenhouse gas fluxes in terrestrial ecosystems. Retrieved March 10, 2021, from https://www.ipcc.ch/srccl/.

Keller, D.R. (Ed.) (2010). Environmental Ethics: The Big Questions. Oxford: Wiley-Blackwell.

Kingsnorth, P. (2017). Confessions of a Recovering Environmentalist. London: Faber \& Faber.

Mollison, B. (1988). Permaculture: A Designers'Manual. Tasmania: Tagari Publications.

Mollison, B., \& Holmgren, D. (1978). Permaculture One: A Perennial Agriculture for Human Settlements. Melbourne, Australia: Transworld Publishers.

Mollison, B., \& Slay, R.M. (1991). Introduction to Permaculture. Tasmania: Tagari Publications.

Rhodes, C.J. (2012). Feeding and healing the world: through regenerative agriculture and permaculture. Science Progress, 95(4): 345-446.

Ripple, W.J., Wolf, C., Newsome, T.M., Galetti, M., Alamgir, M., Crist, E., Mahmoud, M.I., Laurance, W.F., 15,364 scientist signatories from 184 countries (2017). World Scientists' Warning to Humanity: A Second Notice. BioScience, 67(12), 1026-1028. DOI: 10.1093/biosci/bix125.

Shepard, M. (2013). Restoration Agriculture: real world permaculture for farmers. Acres U.S.A.: Austin, Texas. Whitefield, P. (2004). The Earth Care Manual. A Permaculture Handbook for Britain and other Temperate Climates. East Meon: Permanent Publications.

Wittmayer, J.M. (2016). Transition Management, Action Research and Actor Roles: Understanding local sustainability transitions. PhD Thesis. Erasmus University Rotterdam. Retrieved March 10, 2021, from https://repub.eur.nl/pub/94385/Wittmayer_phd_final_incl-layout.pdf. 